\title{
Variants
}

The Journal of the European Society for Textual

Scholarship

12-13 | 2016

Varia

\section{Johnny Kondrup, Editionsfilologi}

\section{Adam Borch}

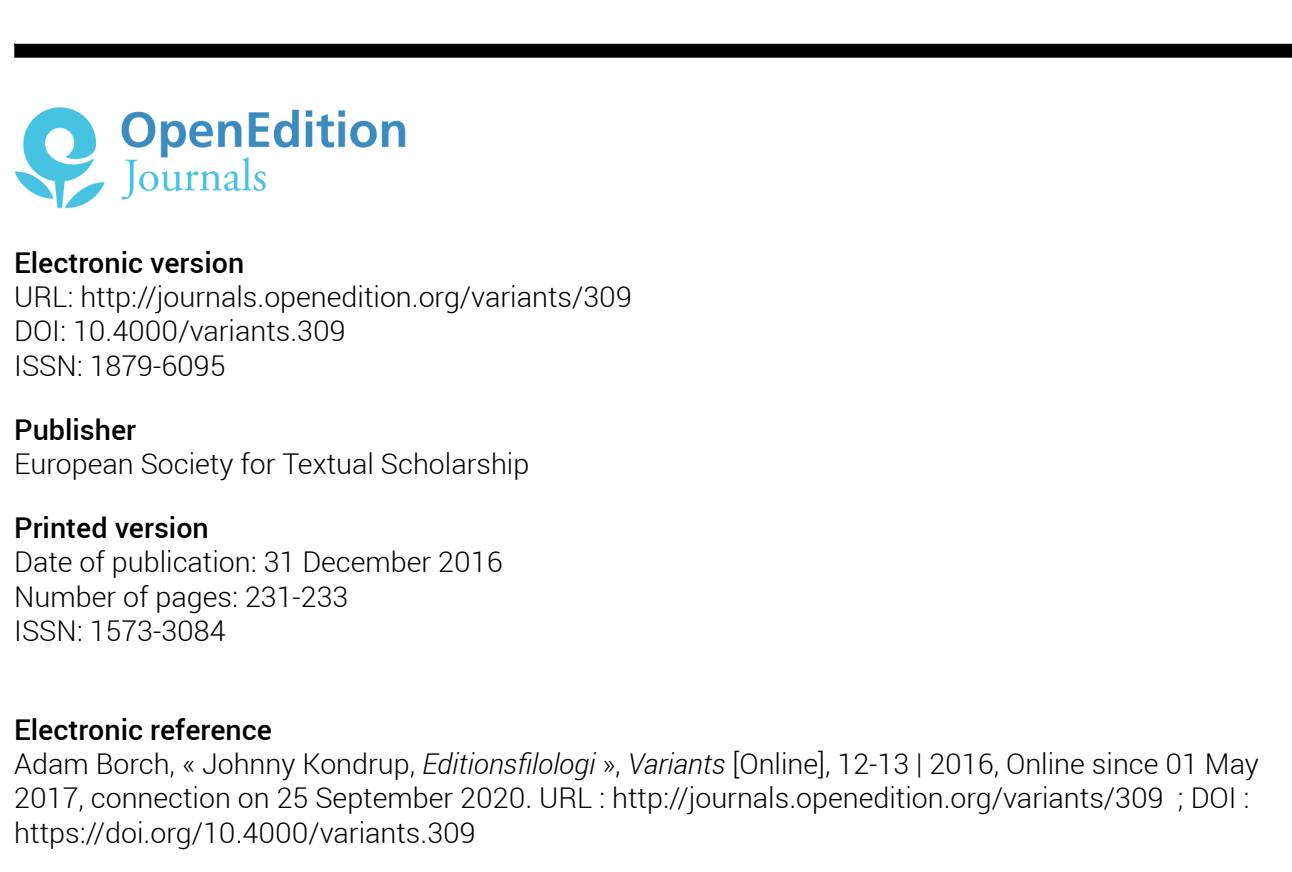

This text was automatically generated on 25 September 2020 .

The authors 


\title{
Johnny Kondrup, Editionsfilologi
}

\author{
Adam Borch
}

\section{REFERENCES}

Johnny Kondrup. Editionsfilologi. Copenhagen: Museum Tusculanums Forlag. 2011. 553

pp. ISBN 978-87-635-3743-8.

1 What one is likely first to notice about Johnny Kondrup's Editionsfilologi is probably the title. In Danish (the book's language), the term is hardly common currency. It does not occur in standard dictionaries (e.g. Den Danske Ordbog) and Kondrup himself reckons it was only first used officially in 1995 when "Nordisk Netværk for Editionsfilologer" was established. It might have its closest relative in the German "Editionsphilologie", but, as he explains, it is also related to "Editionswissenschaft". In an Anglo-American tradition, the definition "videnskaben om udgivelse eller genudgivelse af litterære værker (ofte såkaldte klassiske eller kanoniske tekster), manuskripter, breve og andre skriftlige dokumenter" $(2011,15)$ ("the science of the publication or republication of literary works (often so-called classical or canonical texts), manuscripts, letters and other written documents") suggests that "scholarly editing" and "textual criticism" are related fields.

2 What precisely falls under the umbrella of "editionsfilologi" is still an open question. Kondrup stresses that "tekstkritikken" ("textual criticism") is the pivotal element, but that in his definition it has a broader scope than one might find elsewhere, extending to include "tekstkritik, variantsapparater, dokumentbeskrivelse (bibliografi og manuskriptbeskrivelse), kommentering og elektronisk udgivelse" (17) ("textual criticism, apparatuses of variant states, document description [bibliography and palaeography], annotation and digital publication"). In addition, it is also concerned with scholarly editions that might not always be considered "critical", but are still aimed at a specialized academic audience (e.g. facsimile and variorum editions).

3 Editionsfilologi is essentially a practical and technical handbook for scholars, publishers, students and others involved or merely interested in the publication of scholarly 
editions of literary works. It is not a comprehensive guide, but focuses on the main areas within its theoretical scope. It has two chapters on textual criticism (Chapters 3 and 4), two on how to deal with variant states (Chapters 5 and 6), two on document description (Chapters 7 and 8), one on annotation and commentary (Chapter 9) and one on digital publications (Chapter 10). These are preceded by an introduction (Chapter 1) and a typological discussion of scientific editions (Chapter 2). Editionsfilologi is intended as a "dialogpartner" (18) ("dialogue partner") for its readers and as such it works very well. Overall, the approach is descriptive rather than normative and authoritative. The discussions are lucid and succinct, and, despite the book's length, it is also easy to find specific information. A detailed table of contents, including all subheadings, allows for a quick overview of each chapter and the inclusion of both a topical and a personal index is a useful feature. One could perhaps have wished it also included a glossary of selected terminology (and not merely the discussion found in Chapter 1), but Kondrup and his publisher have, generally, produced a handbook that is well organized and simple to navigate.

Within the field of modern textual scholarship, Editionsfilologi is most directly associated with strands focusing on the study of the sociology of texts ("det tekstsociologiske synspunkt"). Kondrup is, for example, critical of the strong focus on authorial intentions underlying both the Germanic principle of Ausgabe letzter Hand and Anglo-American copy-text theory (2011, 26-29 and 89-112). He argues that a literary work is not synonymous with one of its versions, but rather the aggregate of all its variant states, while stressing the importance of considering all aspects of the publication process that could have influenced a given version of a work (e.g. printers and editors). Equally central to the book's framework is the connection with hermeneutics which is seen not only as a way for "editionsfilologi" to reconnect with traditional literary criticism but also as a source of important self-reflection within the field (2011, 21-24). Kondrup dispels the idea of a "definitive" scholarly edition as well as the opinion that "editionsfilologi" is an objective science, a craft alone. Instead, he presents us with a timely reminder of the limits and consequences of scholarly editing. The process of editing literary texts for publication is always a matter of interpretative choices made from specific temporal, spatial and even ideological positions and these choices all have a concrete impact on how literary texts are interpreted by readers.

Editionsfilologi addresses itself to a relatively small academic community. As mentioned, it is written in Danish. It is also meant to fill a distinct gap in Danish scholarship and it draws most of its examples from Scandinavian literature and scholarship. ${ }^{1}$ It is, in other words, situated squarely within a Danish and Scandinavian critical tradition. This might suggest that its primary justification somehow hinge $\backslash s$ on its potential readership. But personally, I do not think this is the case. Editionsfilologi contains much that would be of interest to a broader international academic community. The chapter on digital publications, for example, gives an interesting and detailed perspective on a rapidly developing field while the chapter on scholarly annotation and commentary provides a thought-provoking discussion of an aspect of scholarly work which still calls for thorough theoretical and methodological treatment. More generally, Kondrup's focus on scholarly and editorial practices in Scandinavian could help to throw new light on practices in other scholarly communities. It is to be hoped that, in the future, Kondrup will find more time to share his views with a broader international audience. 


\section{NOTES}

1. The last work of a similar kind was Paul V. Rubow's Den kritiske Kunst (1938).

\section{AUTHORS}

ADAM BORCH

Adam Borch is a PhD Student at Åbo Akademi University, Finland. His doctoral dissertation is a communicational reading of Alexander Pope's satirical poem The Dunciad, with special focus on the poem's addressivity. 